$\xi=-1$

\title{
Influence of Social Construct on Consumers' Brand Purchase Intention: a Review of Research
}

\author{
Bikash Kumar Rup, Jyotiranjan Gochhayat, and Sasmita Samanta \\ KIIT Deemed to be University, Patia, Bhubaneswar-24, Odisha, India \\ *Corresponding author Email: bikashrup@gmail.com,gochhayatjg@gmail.com,drsasmita@kiit.ac.in
}

\begin{abstract}
:
The aim of this study is to reveal the impact and influence of social construct on consumers' brand purchase intention. Within the study the latent idea is to illuminates the influence of social construct on brand personality, which leads to enhance the brand purchase intention. The flow of effect of social construct is directly to purchase intention or through brand attitude. In different cultural point of view the specific dimensions of brand personality, those are more influential on purchase intention need to be identified. The outcome of the study may helpful for marketers to redesign their marketing strategy in accordance with the consumers brand personality.
\end{abstract}

Keywords: Social construct; Perceived brand personality; Gender role; Brand attitude; Brand purchase intention

\section{Introduction}

A social construct in its simple sense means a social mechanism that is created and developed by society based on ideas and perceptions of individuals or group constructed through social practice like, perceived brand personality, buyers' attitude, beliefs, emotions and such other factors. While addressing social construct in consumers' brand purchase intention, different factors come into picture. In cut throat competition era getting a consumer, meeting the consumer profitably and eventually maintaining the consumer for a long time is a mammoth task. All verticals of an organization depend upon the interests of consumers. Making the consumer aware regarding the product/service, is the foremost step of sales and marketing. While creating the awareness through different process waves an amiable situation, brand allurements enhances this frequency. Brand has the power to wither all competitions. This is one of the smallest steps in cutting the cut throat competition, but in later stage it snowballs into long term strategy. Brand allurement is nothing but the capacity of the brand to attract the consumers towards it (Kotler, 1991). Some school of thoughts argue that brand is a lifeless entity, where as disciples of other different schools argue that brand has also specific disposition/ attributes just like human being. Brand personality is nothing but basic set of human characteristics associated with brands. These personality dimensions play the critical role while portraying consumer affinity towards the specific brand (Hultman et al., 2015; Gordon et al., 2016; Molinillo, Japutra, Nguyen, and Chen, 2017). Researchers such as Aaker (1997) and Geuens et al., (2009) have identified certain brand personality attributes, which are widely referred by both marketers and academicians. Aker (1997) has emphasized on brand personality dimensions such as sincerity, excitement, competence, sophistication, and ruggedness, and Geuens et al. (2009) have identified brand personality attributes such as responsibility, activity, aggressiveness, simplicity, and emotionality.

\section{Perceived Brand Personality}

As per Keller, (1993) brand personality is the one of the drivers of consumer based brand equity and brand personality is regarded as the human attributes related with brand (Aaker, 1997). Brand equity is the innermost construct in the marketing literature and has chief proposition for brand administration (Barwise, 1993; Keller, 1993). Brand equity is defined as the incremental efficacy of a branded product contrast to its non branded equivalent (Aaker, 1991). High brand Equity relates to the higher consumer satisfaction eventually causative to amplify sales and profits by providing enormous effectiveness of transaction (Gupta, Lehmann, \& Stuart, 2004). The measurement of intangible brand association is often operationalised using measures of brand personality (Eisend and Stockburger-Sauer, 2013; Davies et al, 2018). Therefore, we can say that brand personality is directly related to sales. Hence, it bears all responsibility for brands market growth and ensuring considerable impact and influence of specific brands among consumers. A Consumer always thinks that brand is their extension (Belk, 1988) because they see their own attributes through brand personality (Aaker, 1997). Constructive brand personality is directly proportional to brand attitudes and purchase intentions (Freling, Crosno,\&Henard, 2011). The main reason is that brand with an alluring personality dole out as a striking rapport cohort (Fournier, 1998) that eventually leads to higher choice with high purchase intentions. Contextually, Grohman (2009) opines that consumer and brand gender analogy impacts on brand related consumer responses.

Brand personality helps marketers to generate a divergent and significant image in the minds of consumers. This helps in product differentiation (Crask and Laskey, 1990); that eventually leads to positive assessment when compared to a generic offering (Upshaw, 1995).due to cut throat competition and technological up gradation and stringent regulations have compelled the marketers to differentiate by the help of functional product aspect. Therefore, brand personality plays the most crucial role to create a 
market effectiveness for the product and it is really difficult for the product category where me-too are pettily available. If the congruity between consumer personality trait and brand personality happens, it automatically creates a differentiation in market. Research has time and again revealed that consumers do not have any obscurity in relating their brands in terms of human personality (Aaker, 1997). Human personality is the logical consequences of inbuilt disposition and practice, behaviors, outlook, mind-set, beliefs, demographic information, and physical facade (Park et al., 1986). On the contrary, Brands are inept of deed and personality must be incidental by their material quality, utility, user metaphors, and circumstances in which the brand is found (Sung and Kim, 2010). Brand personality in its simple sense is considered a set of human characteristics connected with a brand. Aaker's (1997) depicted Brand Personality Scale (BPS) as shown in table 1 .

Table 1: Brand Personality Scale

\begin{tabular}{|l|l|l|l|l|}
\hline Sincerity & Excitement & Competence & Sophistication & Ruggedness \\
\hline$\bullet \quad$ Down to earth & $\bullet$ Daring & $\bullet$ Reliable & $\bullet$ Upper class & $\bullet$ Outdoorsy \\
$\bullet \quad$ Honest & $\bullet$ Spirited & $\bullet$ Intelligent & $\bullet$ Charming & $\bullet$ Tough \\
\hline$\quad$ Cheerful & $\bullet$ Imaginative & $\bullet$ Successful & & \\
\hline
\end{tabular}

Sources: Aaker (1997)

Although Aaker's five magnitude of brand personality has acted as important extent instrument, but some loopholes (Austin et al., 2003; Azoulay and Kapferer, 2003) necessitate the assessment of substitute scales. Inadequacy of the scale comprise of (mentioned below):

1. The methodological precincts resultant from factor analysis (Sweeney and Brandon, 2006)

2. The span of the scale extends beyond brand personality and includes magnitude of brand identity such as user-image and socio-demographic distinctiveness like age or gender (Azoulay and Kapferer,2003)
3. The scales do not allow for negative personality such as unreliability or selfishness (Kaplan et al., 2010); and

4. The non generalizability of the scale for a specific brand within a specific product category (Austin et al., 2003).

Geuens et al. (2009) constituted a new gauge of brand personality. Their five-factor solution consists of twelve items was restricted to personality traits and excluded functional characteristic demographic uniqueness, user imagery and user manifestation, which is depicted in table 2.

Table 2: A New Gauge of Brand Personality

\begin{tabular}{|c|c|c|c|c|}
\hline Responsibility & Activity & Aggressiveness & Simplicity & Emotionality \\
\hline $\begin{array}{ll}\text { - } & \text { Down to earth } \\
\text { - } & \text { Stable } \\
\text { - } & \text { Responsible }\end{array}$ & $\begin{array}{ll}\text { - } & \text { Active } \\
\text { - } & \text { Dynamic } \\
\text { - } & \text { Innovative }\end{array}$ & $\begin{array}{ll}\text { - } & \text { Aggressive } \\
\text { - } & \text { Bold }\end{array}$ & $\begin{array}{ll}\text { - } & \text { Ordinary } \\
\text { - } & \text { Simple }\end{array}$ & $\begin{array}{ll}\text { - } & \text { Romantic } \\
\text { - } & \text { Sentimental }\end{array}$ \\
\hline
\end{tabular}

Sources: Geuens et al. (2009)

Brand personality is a multidimensional and complex construct (Aaker 1997). It facilitates consumers to articulate themselves along several extents. Consumers correlate human personality persona with brands since they narrate to brands as they would to cohorts (Fournier 1998). Moreover, consumers recognize brands as annex of their selves (Belk 1988).

The marketing literature advocates that out of basic instinct of human behavior, consumers want to see brands as they feel themselves: be in feminine quality or in masculine, this is nothing but the derivation of self concept and seeing the own self through the mirror (Sirgy, 1982). Therefore, gender magnitude of personality emerges to be pertinent to brands that have figurative assessment for consumers trying to buttress their own masculinity and femininity. Practically this is also highly required in marketing place to generate congruence between consumers thinking with marketers thinking.

What a consumer thinks or perceives in his mind about a brand is his/ her perceived brand personality towards the specific brand. So the perceived brand personality is nothing but the specific attribute the consumer perceives towards the specific brand. When the congruity between the perceived brand personality and brand personality happens, the purchasing intention enhances enormously.

Buyers brand purchase intention towards a specific brand is created if and only if the inclination of buying a product is found in the customer. Intention may be high or low, but it leads to purchasing behavior (Crosno, Freling \& Skinner, 2009). In today's market brand consumption is a matter of prestige and it is growing day by day. Therefore, research in the aforesaid direction is also growing in the same spree to help marketers to identify the specific reason behind the purchasing intention. Is it really the perceived brand personality creating possibilities in purchasing intention or else any other factor such as brand attitude or perceived brand personality mediating through attitude reaching to purchasing intention? Buyers brand attitude is a long term phenomenon, which is nothing but continuous evaluation of specific brand and its experience. This relation is directly proportional. But it is confusing whether brand personality is one and only one predictor or catalyst or some other latent catalysts are present in the process, if so then up to which extent?

Some scholars argue that it is biological sex; male and female impacts perceived brand personality nurturing process. But other school of thought contradicts that it is more of social constructs; gender role less of biological construct; male and female.

\section{Gender Role}

As per Yorburg, 1974, how we think about our self as men or as women consists of gender identity. How we behave whether masculine or feminine is related to our behavior and attributes. Some argue that this is a psychological construct, but other believes that this is also a social construct, because this mirrors our social thinking (Harris, 1998). This is always divergent from sex, though always ambiguous in literature and also in thinking. The building of gender identity occurs early in human growth. At age two, a kid has significant gender familiarity and can utilize the words girl or boy correctly in referring to him/ herself (Katz, 1986). We are finished conscious of our gender at a near the beginning age, and once our nucleus gender identity is created it is hard to modify (Katz, 1986; West and Zimmerman, 1998).How we think and behave in due course of time represents our gender role. As per Erikson, establishing gender role is vital in adolescent age, because this determines personal identity, which also helps to eradicate identity bewilderment (Erikson, 1963, 1968). Gender role is skilled through day to day action. By virtue of his or her action he is called he or she (Salminen-Karlsson, 2006). Gender divergences are identified as social behavior (Campbell et al., 2004). There are inconsistent results with respect to the relative 
significance of masculinity and femininity in explaining findings. For example, some researchers establish masculinity to be a noteworthy forecaster of consumer purchase intentions (Coughlin and O'Connor, 1985) whilst other found that femininity to be more important than masculinity (Fischer and Arnold, 1990) specifically in case of Christmas gift shopping. Sex is one of the most elementary of demographic classifications and is used in every social science and management research (Connell, 1987). Many researchers like Bem (1974), Iyer and Debevec (1986), Milner et al. (1990), Milner and Fodness (1996) and others argued: whether a product, like a person, has gender? Time and again, they established that most products had gender, and this also applies to still services (Stern et al., 1993). According to Woolfolk (1995), consumers build up gender identities for themselves and products; this is also helped by the image conversed by the marketers through media. To uphold gender image veracity, consumers mostly procure products that have gender identities congruent with their own (Milner and Fodness ,1996).

Consumption behavior is tacit to be consistent with a person's gender identity. This also proved that both sexes have psychologically sore using products and services which do not seem to be made for them. Both sexes subconsciously want to use the socially fit product for themselves (Milner and Fodness, 1996). Self-congruency conjecture individuals use products, which mirror their own picture or identity; which also imply more applicability of self concept and less of functional attributes of the specific product (Grubb and Grathwohl, 1967).

Consequently, it is also vital and also not startling that "Advertisers often work to create a gender image for a brand by featuring the targeted gender in an advertisement as a 'typical' user of the product" (Debevec and Iyer, 1986). Gender role is essentially per formative. One be trained how to take part in a masculine or feminine role, what is up to standard and what is not, how one should perform, imagine, and appraise oneself. Whilst age, ethnicity, class, and many other aspects have culturally approved standard, gender role is the most widespread and significant social systematize code (Roopnarine and Mounts, 1987). A person's gender role is unruffled of several fundamentals and can be articulated through attire, deeds, choice of work, individual associations and other dynamic. Gender roles were conventionally alienated into sternly feminine and masculine gender roles, nonetheless these roles have branch out today into many diverse tolerable male or female gender roles. Still, gender role standard for women and men can contrast radically from one country or culture to another, even within a country or culture. Populace utters their gender role somewhat inimitably. Gender role can show a discrepancy according to the societal assemblage to which a person fit in or the subculture with which he or she opt to classify.

Evidence is already there to justify gender differences in decisionmaking processes of individuals such as financial decision-making (Powell and Ansic, 1997), attributes important in determining selfesteem (Tashakkori, 1993), emotional expression (Deaux, 1985; Kring and Gordon, 1998), and communication or conversational style (Tannen, 1995).

Though the outcome was conflicting in nature, from the result (masculinity and femininity) point of view, gender identity was emerged as pivotal player (Fischer and Arnold, 1990; Jaffee, 1991) masculinity is an important forecaster of purchasing intention (Coughlin and O'Connor, 1985), femininity is the construct better than masculinity (Fischer and Arnold, 1990). Studies have revealed that biological sex has more impact on consumer behaviour (Gould and Weil, 1991).while dealing about consumer behaviour; attitude also acts as a vital catalyst. If consumers have favourable attitude towards a brand, it will help in creating a higher preference for the brand, minimizing the negativities around it.

\section{Brand Attitude}

Buyer's brand attitude (BA) can be referred to the steady estimation of a brand, feeling towards a brand and inclination in the direction of a brand of a buyer (Armstrong \& Kotler, 2000; $\mathrm{Wu} \mathrm{S}, 2003$ ). Attitude is the summation of all emotions, prospect, conviction, principles, and beliefs of a buyer (Bagozzi, 1994, Malhotra, 2005) towards a product/service. An assortment of aspect such as personal familiarity, knowledge, information, news, media \& direct/indirect experience of life (Wu S, 2003) can manage buyers' attitude towards a particular brand. Tripartite model of attitude (Blackwell et al., 2001; Schiffman \& Kanuk, 2004) suggests that, attitude consists of the philosophy of the buyer, feelings, and emotions of the buyer, and behavioural objective of the buyer. Accordingly, buyers' overall attitude towards a brand can be copied by assessing the beliefs, feelings, and emotions of the buyer towards the specific brand.

\section{Buyer Brand Purchase Intention}

Buyers' brand purchase intention (BPI) can be defined as the purpose of a buyer to acquire a product or service of particular brand if he/she has to buy it. It replicates the likelihood and possibility that the buyer will purchase the brand (Crosno, Freling \& Skinner, 2009). BPI can be predisposed by different cognitive $\&$ perceptual aspect such as name alertness, brand association, and perceived quality (Aaker, 1991). Theory of reasoned action advocates that behavioural purpose of the consumer leads to behaviour (Fishbein \& Ajzen, 1975; Son, Jin, Gerge, 2013), playing a pivotal role in buyer's actions (Pierre et al., 2005; Schlosser et al., 2006), and extent of buyers' brand consumption (Yoo \& Lee, 2009).

Gender roles can be socially constructed roles, behaviors, activities, and attributes that a given society considers appropriate for men and women and reflects the social and psychological sex of the person (Suar and Gochhayat, 2016). Both sexes have different gender role as per social perceptions. Male are expected to behave in specific way and females are expected to manifest specific attributes, but those expected dispositions are not theirs copyright, they may behave defiantly and differently also. Therefore, perceived brand personality acts as the hub around which sex, gender role, buyers brand attitude, and buyers brand purchase intention revolve that is depicted in figure 1.

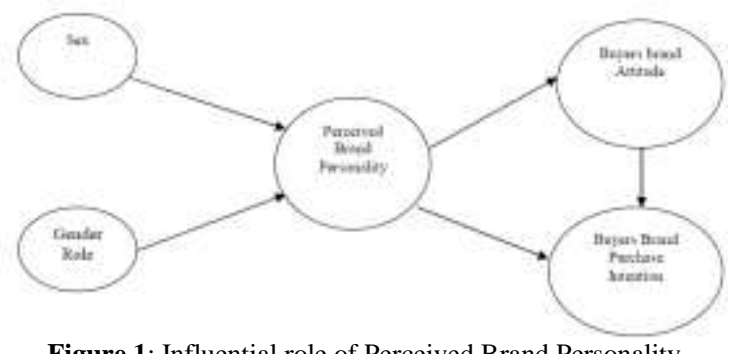

Figure 1: Influential role of Perceived Brand Personality Source: Prepared by author

It is understood from figure 1 that perceived brand personality is influenced by more of gender role and less of sex factor, which eventually leads to higher buyers brand purchase intention through buyers brand attitude.

\section{Conclusion}

Comprehending all the published literature, it is understood that social construct such as gender role plays significant role in perceiving the brand personality in consumers point of view, earlier it was thought that sex was playing the pivotal role while defining the perceived brand personality. It largely depends upon 
human personality, their behaviors, outlook, mind-set, beliefs, and other assorted traits. In understanding the relationship between perceived brand personality, brand attitude and brand purchase intention, this study provides an understanding of different brand personality attributes \& their influence on brand purchase intention through the mediating effect of brand attitude. The finding will help the marketers to redefine the marketing strategy. Organisations may focus on suitable message so as to incarcerate the desire of their target consumers. The organizations can remodel their product delineation to position the brand in market to augment the conversion rate of potential customers.

The marketers must be familiar with the scale of culture in shaping Indian consumer's insight of brands so that their purchase actions can be better diagnosed. It is imperative for brand mangers to grasp how consumers pick out the brand.

\section{References}

[1] Aaker, D. A. (1991), "Managing brand equity", New York: The Free Press.

[2] Aaker, D. A. (1996), "Measuring brand equity across products and markets", California Management Review, Vol.38, pp.102120.

[3] Aaker, J. L. (1997), "Dimensions of brand personality", Journal of Marketing Rresearch, Vol. 34, No. 3, pp.347-356.

[4] Armstrong, G., and Kotler, P. (2000), "Marketing", Prentice-Hall, Englandwood Cliffs, NJ, pp.153-154.

[5] Austin, J.R., Siguaw, J. and Mattila, A. (2003), "A reexamination of the generalizability of the Aaker brand personality framework", Journal of Strategic Marketing, Vol. 11 No. 2, pp. 77-92.

[6] Azoulay, A. and Kapferer, J-N. (2003), "Do brand personality scales really measure brand personality?", Journal of Brand Management, Vol. 11 No. 2, pp. 143-155.

[7] Bagozzi, R.P. (1994), "Principles of Marketing Research", Blackwell Business, Oxford.

[8] Barwise, P. (1993), "Brand equity: Snark or Boojum?" International Journal of Research in Marketing, Vol.10, pp.93-104

[9] Belk, R. W. (1988), "Possessions and the extended self", Journal of Consumer Research, Vol.15, pp.139-168.

[10] Belk, Russell W. (1988), "Possessions and the Extended Self," Journal of Consumer Research, Vol. 2 No.2, pp.139-68.

[11] Blackwell, R.D., Miniard, P.W., and Engel, J.F. (2001), "Consumer Behaviour", Harcourt College Publishers, Fort Worth, TX

[12] Campbell, A., Shirley, L. and Candy, J. (2004), "A longitudinal study of gender-related cognition and behavior", Developmental Science, Vol. 7 No. 1, pp. 1-9.

[13] Connell, R.W. (1987), "Gender and Power", Stanford University Press, Stanford, CA.

[14] Crask, M.R. and Laskey, H.A. (1990), "A positioning-based decision for selecting advertising messages", Journal of Advertising Research, Vol. 30 No. 4, pp. 32-38.

[15] Crosno, J.L., Freling, T.H., and Skinner, S.J. (2009), "Does bran social power mean market might? Exploring the influence of brand social power on brand evaluations", Psychology \& Marketing, Vol.26No.2, pp.91-121.

[16] Deaux, K. (1985), "Sex differences", in Rosenzweig, M.R. and Porter, L.W. (Eds), Annual Review of Psychology, 26, Annual Reviews, Palo Alto, CA, pp. 48-82.

[17] Debevec, K. and Iyer, E. (1986), "Sex roles and consumer perception of promotions, products, and self: what do we know and where should we be headed?", in Lutz, R.J. (Ed.), Advances in Consumer Research, Association for Consumer Research, Ann Arbor, MI, pp. 210-14

[18] Davies, G, et al.(2018), "Brand personality: theory and dimensionality", Journal of Product \& Brand Management, Vol.27 No. 3, pp.115-127.

[19] Eisend, M and Stockburger-Sauer, N. E. (2013), "Brand Personality: a meta analytic review of antecedents and consequences", Marketing Letters, Vol.24 No. 3, pp.2015-216.

[20] Erikson, E. (1963), "Childhood and Society", Norton, New York, NY.

[21] Erikson, E. (1968), "Identity, Youth, and Crisis", Norton, New York, NY.
[22] Fisbein, M., \& Ajzen, I. (1975), "Belief, attitude, intention and behavior: An introduction to theory and research", Massachusetts, Addison-Wiley Publishing Company.

[23] Fischer, E. and Arnold, S.J. (1990), "More than a labor of love: gender roles and Christmas gift shopping", Journal of Consumer Research, Vol. 17, pp. 333-45.

[24] Freling, T., Crosno, J. L., \& Henard, D. H. (2011), "Brand personality appeal: Conceptualization and empirical validation", Journal of the Academy of Marketing Science, Vol.39, pp.392-406.

[25] Geuens, M., Weijters, B., and De-Wulf, K. (2009), "A new measure of brand personality", International Journal of Research in Marketing, Vol.26 No.2, pp.97-107.

[26] Gordon, R., Zainuddin, N. \& Magee, C. 2016. Unlocking the potential of branding in social marketing services: utilising brand personality and brand personality appeal. Journal of Services Marketing, Vol.30, pp.48-62.

[27] Gould, S.J. and Weil, C.E. (1991), "Gift-giving roles and gender self-concepts”, Sex Roles, Vol. 24 Nos 9/10, pp. 617-37.

[28] Grohmann, B. (2009), "Gender dimensions of brand personality", Journal of Marketing Research, Vol. 46 No. 1, pp. 105-119.

[29] Grubb, E.L. and Grathwohl, H.L. (1967), "Consumer selfconcept, symbolism and market behaviour: a theoretical approach", Journal of Marketing, Vol. 31 No. 4, pp. 22-7.

[30] Gupta, S., Lehmann, D. R., and Stuart, J. A. (2004), "Valuing customers" Journal of Marketing Research, Vol.41, pp.7-18.

[31] Harris, J.R. (1998), "The Nurture Assumption", Free Press, New York, NY.

[32] Hultman, M., Skarmeas, D., Oghazi, P. and Beheshti, H. M (2015), "Achieving tourist loyalty through destination personality, satisfaction, and identification", Journal of Business Research, Vol.68, pp.2227-2231.

[33] Jaffee, L.J. (1991), "Impact of positioning and sex-role identity on women's responses to advertising", Journal of Advertising Research, June/July, pp. 57-64.

[34] Kaplan, M.D., Yurt, O., Guneri, B. and Kurtulus, K. (2010), "Branding places: applying brand personality concept to cities", European Journal of Marketing, Vol. 44 Nos 9/10, pp. 1286-1304.

[35] Katz, P.A. (1986), "Gender identity: development and consequences", in Ashmore, R.D. and Del Boca, F. K. (Eds), The Social-Psychology of Female-Male Relations: A Critical Analysis of Central Concepts, Academic Press, New York, NY, pp. 2-67.

[36] Keller, K. L. (1993), "Conceptualizing, measuring, and managing customer-based brand equity", Journal of Marketing, Vol.57, pp.122.

[37] Kotler, Philip H. (1991), "Marketing Management: Analysis, Planning, and Control", 8th ed. Englewood Cliffs, NJ:Prentice-Hall, Inc.

[38] Kring, A.M. and Gordon, A.H. (1998), "Sex differences in emotion: expression, experience, and physiology", Journal of Personality and Social Psychology, March, pp. 686-703.

[39] Malhotra, N.K. (2005), "Attitude and affect: new frontiers of research in the 21st century", Journal of Business Research, Vol.58 No.4, pp. 477-82.

[40] Milner, L.M. and Fodness, D. (1996), "Product gender perceptions: the case of China", International Marketing Review, Vol. 13 No. 4, pp. 40-51

[41] Milner, L.M., Speece, W.W. and Anderson, J. (1990), "Product gender perceptions: the case of Greeks", in Synodinos, N.E. (Ed.), Proceedings of the 3rd Symposium on Cross-cultural Consumer and Business Studies, Honolulu,HI, pp. 404-14.

[42] Molinillo, S., Japutra, A., Nguyen, B., \& Chen, C. H. S. (2017) "Responsible brands vs active brands? An examination of brand personality on brand awareness, brand trust, and brand loyalty", Marketing Intelligence \& Planning, 35(2), 166-179

[43] Park, C. S., \& Srinivasan, V. S. (1994), "A survey-based method for measuring and understanding brand equity and its extendibility", Journal of Marketing Research, vol.31, pp.271-288.

[44] Park, C., Jaworski, B.J. and MacInnis, D.J. (1986), "Strategic brand concept-image management", Journal of Marketing,Vol. 50 No. 4 , pp. 125-145

[45] Pierre, C., Morwitz, V.G., and Reinartz, W.J. (2005), "Do intentions really predict behavior? Self-generated validity effects in survey research", Journal of Marketing, Vol. 69 No.2, pp.1-14.

[46] Powell, M. and Ansic, D. (1997), "Gender differences in risk behavioral in financial decision-making: an experimental analysis", Journal of Economic Psychology, Vol. 18, pp. 605-28.

[47] Roopnarine, J.L. and Mounts, N.S. (1987), "Current theoretical issues in sex roles and sex typing", in Carter, D.B.(Ed.), Current 
Conceptions of Sex Roles and Sex Typing: Theory and Research, Praeger, New York, NY, pp. 7-32.

[48] Salminen-Karlsson, M. (2006), "Situating gender in situated learning", Scandinavian Journal of Management, Vol. 22 No. 1, pp. $31-48$.

[49] Schiffman, L.G., \& Kanuk, L.L. (2004), "Consumer Behaviour", 8th ed., Pearson Education, Upper Saddle River, NY.

[50] Schlosser, A.E., White, T.B., and Lloyd, S.M. (2006), "Converting web site visitors into buyers: how web site investment increases consumer trusting beliefs and online purchase intentions" Journal of Marketing, Vol.70, 133-148.

[51] Shwu- Ing Wu (2003), "The relationship between consumer characteristics and attitude toward online shopping", Marketing Intelligence \& Planning, Vol.21No.1, pp.37-44.

[52] Sirgy, M. Joseph (1982), "Self-Concept in Consumer Behavior," Journal of Consumer Research, Vol. 9 No.3, pp. 287-300.

[53] Son, J., Jin, B., \& George, B. (2013), "Consumers' purchase intention toward foreign brand goods" Management Decision, Vol.51No.2, pp.434-450.

[54] Stern, B.B., Gould, S.J. and Tewari, S. (1993), "Sex-typed service images: an empirical investigation of self-service variables", Service Industries Journal, Vol. 13 No. 3, pp. 74-96.

[55] Suar, D. and Gochhayat, J. (2016), "Influence of biological sex and gender roles on ethicality". Journal of business ethics, Vol.134, pp.199-208.

[56] Sung, Y. and Kim, J. (2010), "Effects of brand personality on brand trust and brand affect", Psychology \& Marketing, Vol. 27 No. 7, pp. 639-661.

[57] Sweeney, J.C. and Brandon, C. (2006), "Brand personality: exploring the potential to move from factor analytical to circuplex models", Psychology \& Marketing, Vol. 23 No. 8, pp. 639-663.

[58] Tannen, D. (1995), Talking from 9 to 5, William Morrow, New York, NY.

[59] Tashakkori, A. (1993), "Gender, ethnicity, and the structure of self-esteem: an attitude theory approach", Journal of Social Psychology, Vol. 133, pp. 479-88.

[60] Upshaw, L. (1995), "Building Brand Identity: A Strategy For Success in a Hostile Market Place", John Wiley, New York, NY.

[61] West, C. and Zimmerman, D.H. (1998), "Doing gender", in Clinchy, B.M. and Norem, J.K. (Eds), The Gender and Psychology Reader New York University Press, New York, NY, pp. 104-24.

[62] Woolfolk, A.E. (1995), Educational Psychology, 6th ed., Allyn \& Bacon, Boston, MA

[63] Yoo, B., \& Lee, S-H., (2009), "Buy genuine luxury fashion products or counterfeits", Advances in Consumer Research, Vol.36, 280-286.

[64] Yorburg, B. (1974), "Sexual Identity: Sex Roles and Social Change", Wiley, New York, NY. 